\title{
Status of shallow Fucales (Ochrophyta) assemblages in the bay of Brucoli, eastern coast of Sicily (Ionian Sea)
}

\author{
Giuliana Marletta \\ University of Catania, Department of Biological, Geological and Environmental Sciences, 95128, Catania, Italy; \\ e-mail: giulianamarletta93@gmail.com
}

\begin{abstract}
The present study investigated the current status of the shallow Fucales assemblages of the bay of Brucoli, located along the eastern coast of Sicily (Italy). Moreover, since most of the studies on these habitat-forming species of this area were ancient, the obtained data were compared with historical data (literature and herbaria) to assess losses, to highlight the eventual sites of regression and identify the possible causes that should be removed. Through the sampling and identification in the laboratory, ten taxa, belonging to the genera Cystoseira, Ericaria, Gongolaria and Sargassum were found. During the sampling, four new species, never reported in the bay of Brucoli, were detected. Through this study, it was noticed that most of the Fucales are absent in the southwest coast and in the central sector of the bay, the most anthropized areas, while the area richest in species is the northeast coast. From this point of view, it would be important to improve the quality of water, and to encourage the conservation of the Fucales assemblages in this area.
\end{abstract}

KEY WORDS Cystoseira; Ericaria; Gongolaria; Sargassum; Fucales; Bay of Brucoli; Sicily.

Received 30.07.2021; accepted 04.12.2021; published online 30.12.2021

\section{INTRODUCTION}

Shallow coastal areas represent some of the most productive, diverse, and threatened marine ecosystems (Harley et al., 2006; Airoldi \& Beck, 2007). The temperate rocky coasts are characterized by the presence of large canopy-forming kelps (Laminariales, Phaeophyceae, Ochrophyta) and fucoids (Fucales, Phaeophyceae, Ochrophyta), which represent the dominant species in pristine environment (Dayton, 1985; Steneck et al., 2002; Schiel \& Foster, 2006). In the eastern Atlantic and in the Mediterranean, canopy-forming algae are mainly formed by Sargassum C. Agardh and Cystoseira s.l. species (Orellana et al., 2019).

These habitat-forming species dominate several assemblages, from the littoral fringe down to the lower sublittoral zone (Feldmann, 1937; Molinier, 1960; Pignatti, 1962; Verlaque, 1987; Ballesteros, 1988, 1990 a, b; Giaccone et al., 1994).
Their zonation depends on different environmental conditions (light, temperature, hydrodynamics and grazing) (Sauvageau, 1912; Ollivier, 1929; Vergés et al., 2009). They generate high primary production contributing to sustaining diversified trophic levels and they provide shelter, food, habitat and nurseries to a multitude of species (Steneck et al., 2002). Therefore, they represent important species in the Mediterranean phytal zone (Feldmann, 1937; Giaccone, 1973). Several species preferentially live in the shallow waters of sheltered coves and bays. These habitats are target areas for human development and some of the species developing in shallow and sheltered environments may be in serious regression along most of their previous distribution range (Thibaut et al., 2005). In fact, during the last decades Fucales have retracted their ranges considerably particularly close to urban areas (Benedetti-Cecchi et al., 2001; Soltan et al., 2001; Thibaut et al., 2005, 
2015; Ballesteros et al., 2007; Mangialajo et al., 2007, 2008; Perkol-Finkel \& Airoldi, 2010), being replaced by structurally less complex communities dominated by turf-forming, or other ephemeral seaweeds, mussels (Benedetti-Cecchi et al., 2001; Connell et al., 2014; Strain et al., 2014) or sea urchin barrens (Agnetta et al., 2015). This decline is due to the cumulative impact of increasing human pressures (habitat destruction, pollution, non-indigenous species, overfishing, coastal aquaculture and global warming) (Cormaci et al., 2001; Thibaut et al., 2005, 2015, 2016; Serio et al., 2006; Mangialajo et al., 2008; Sales \& Ballesteros, 2009; Tsiamis et al., 2013; Templado, 2014; Mineur et al., 2015). Different forms of stress act over time and in unison, with a possible synergistic effect, on species, ecosystems and their ability to deliver ecosystem services (e.g. Worm et al., 2006; Halpern et al., 2008; Waycott et al., 2009).

The sensitivity of canopy-forming algae to a variety of anthropogenic stressors is increasingly well understood (Ballesteros et al., 2007; Mangialajo et al., 2007; Asnaghi et al., 2009; Sales et al., 2011), making these systems useful indicators of water and ecosystem quality according to the Water Framework Directive (2000/ 60/EC) (Commission E., 2000).

Some Cystoseira complex species are under surveillance by international organizations such as the Council of Europe, the United Nations, the IUCN, the RAC/ASP, the WWF and MedPan. Moreover, the Berne Convention (Annex I, Council of Europe, 1979) and the Barcelona Convention (Annex II, UNEP/MAP, 2009) protects them and they are listed as Habitat of Community Interest by the UE (Micheli et al., 2013).

Despite its recognized value and vulnerability, data on the distribution and status of Fucales habitats are surprisingly limited and ecological analyses for many areas are rare (Mancuso et al., 2018). In addition to this, while many regions have experienced dramatic loss of these ecosystems (Airoldi et al., 2014; Thibaut et al., 2015), in other regions losses have been limited to the most severely impacted sites and some populations have surprisingly persisted in a relatively healthy status (Thibaut et al., 2014). Understanding what factors or combinations of factors control the ultimate distribution and conditions of these ecosystems is a key priority to establish effective conservation measures (Mancuso et al., 2018) and to provide a possible restauration program.

From this point of view, it is important to keep monitoring coastal areas, especially those most prone to anthropogenic factors. The object of this study is the bay of Brucoli (Fig. 1), an area located in the eastern coast of Sicily (Italy), that for over forty years has been subjected to anthropogenic impacts, due to the presence of a sewage, the high number of both summer residences and yachtsmen frequenting its coasts (Messina, 2013). Nevertheless, despite these impacts, in this area there is a well-structured Posidonia oceanica (L.) Delile meadow that represents most of the submerged vegetation of the bay.

Because most of the studies on the Fucales in this area are ancient (Battiato \& Ponte, 1975; Battiato et al., 1978; Battiato et al., 1980; Furnari et al., 2003), the aim of this study was firstly to gain knowledge of the species currently present. Furthermore, con-

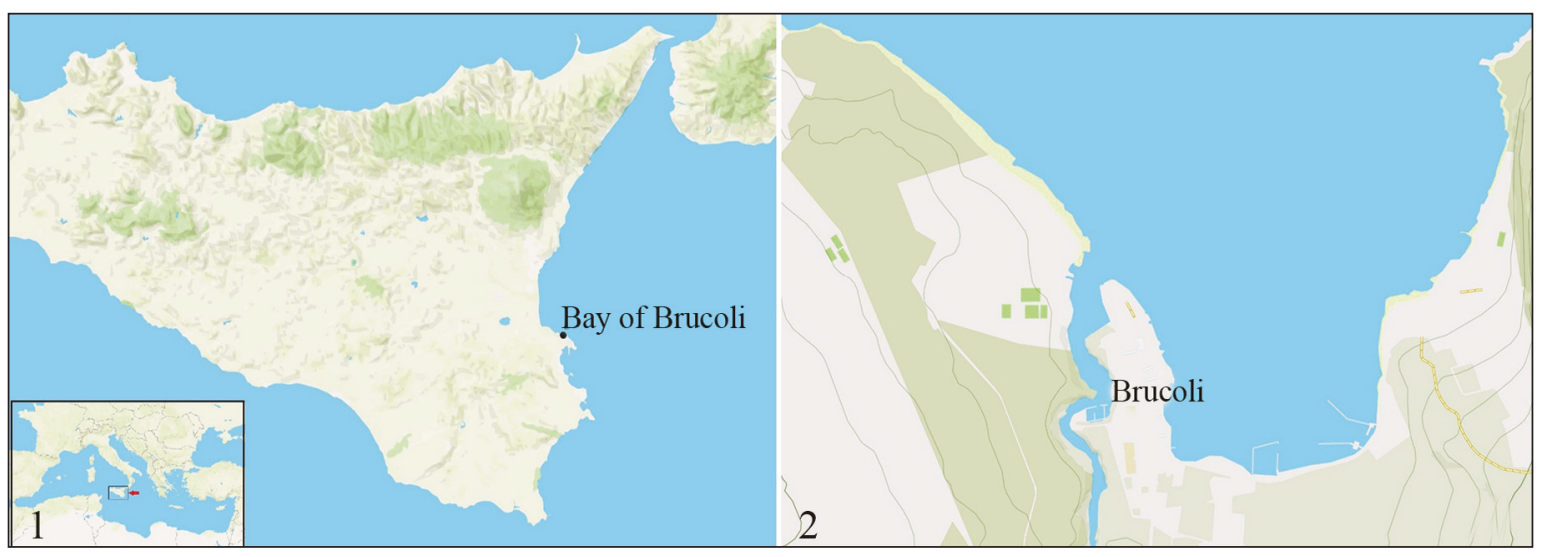

Figures 1, 2. Study area. Fig. 1: location of the study area in the eastern coast of Sicily (Ionian Sea). Fig. 2: detail of the bay Brucoli (Augusta). 
sidering a possible restauration program, the present populations have been compared with historical data (literature and herbaria) to assess losses, to highlight the eventual sites of regression and identify the possible causes that should be removed.

\section{MATERIAL AND METHODS}

The bay of Brucoli $\left(37.284167^{\circ} \mathrm{N}, 15.187778^{\circ}\right.$ E), located between Catania and Syracuse (eastern coast of Sicily), is a natural basin situated in the municipality of Augusta (Fig. 2). The coastline of the bay is interrupted, in the south-western part, by an estuary of the Porcaria Channel which forms jagged inlets. Thanks to the presence of the $P$. oceanica meadow, the Bay of Brucoli is included in the Nature 2000 network as a Site of Community Importance named: "SIC-ITA090026 Fondali di Brucoli - Agnone" (Nisi, 2012).

The samplings were carried out during June, July and October 2019 to compare summer and autumn stands. The area between the coastline and the beginning of $P$. oceanica meadow, where the Fucales communities are located, was surveyed by snorkeling. Furthermore, samples were collected in the eastern side and in the western side of the bay, while the central sector, where there are floating piers, was only surveyed through snorkeling. For each species, two thalli were collected with a pick to include the base; subsequently they were stored with seawater and alcohol and identified in the laboratory. Then, the collected thalli were stored in exsiccata.

Moreover, through snorkeling, the abundance of the species was visually estimated and the following categories were considered: absent, isolated individuals, scattered populations and dense populations (Thibaut et al., 2016). Finally, to gain historical data, previous studies on the Fucales of Brucoli were consulted (Battiato \& Ponte, 1975; Battiato et al., 1978; Battiato et al., 1980; Furnari et al., 2003).

\section{RESULTS}

Through the samplings and identification in the laboratory, ten taxa of the family Sargassaceae Kützing were found: three belonging to the genus Ericaria Stackhouse, two to the genus Gongolaria Boehmer, four to the genus Cystoseira C, Agardh, and one to the genus Sargassum. Most of the species are Mediterranean endemisms, except for Cystoseira compressa (Esper) Gerloff \& Nizamuddin, C. foeniculacea (Linnaeus) Greville and C. humilis Schousboe ex Kützing, distributed also in the eastern Atlantic, and Sargassum vulgare C. Agardh, which is even present in tropical and subtropical oceans.

A list of the Fucales found in the bay of Brucoli is given below. For every species data on the present distribution, the abundance, the main diacritical characters and any previous reports have been included.

\section{Ericaria amentacea (C.Agardh) Molinari et Guiry} (Figs. 3-5)

Ericaria amentacea is present both in the east and in the west side of the bay of Brucoli. Largesized thalli have been observed in summer, especially in the station of Punta Tonnara (the northernmost site on the eastern side of the bay) and in the southeast coast where there are dense populations of this species frequently associated with populations of Ericaria mediterranea (Sauvageau) Molinari \& Guiry. During the summer sampling, fertile thalli were observed, while in autumn receptacles were not found.

This species was reported in historical data of the bay of Brucoli as Cystoseira stricta (Battiato et al., 1980) and in 1974 as Cystoseira amentacea var. stricta (Furnari et al., 2003).

This species lives in the infralittoral fringe, particularly in exposed coasts. The specimens found by us corresponds to the description of Gómez Garreta et al. (2000) and Cormaci et al. (2012): caespitose thalli attached to the substratum by haptera, spinose and not prominent apex, spines present both in primary and secondary branches. Primary branches are cylindrical and the base of them, usually in spring, is unbranched. The receptacles located at the apices of all branches are compact and the conceptacles are at the base of the spines.

\section{Ericaria brachycarpa (J.Agardh) Molinari et Guiry} (Figs. 6-8)

Ericaria brachycarpa is present both in the northeast and in the northwest coasts of the bay of Brucoli where there are dense populations. It was not found in the southernmost part of the bay, probably because this species prefers moderately exposed and high light-intensity places (Gómez 


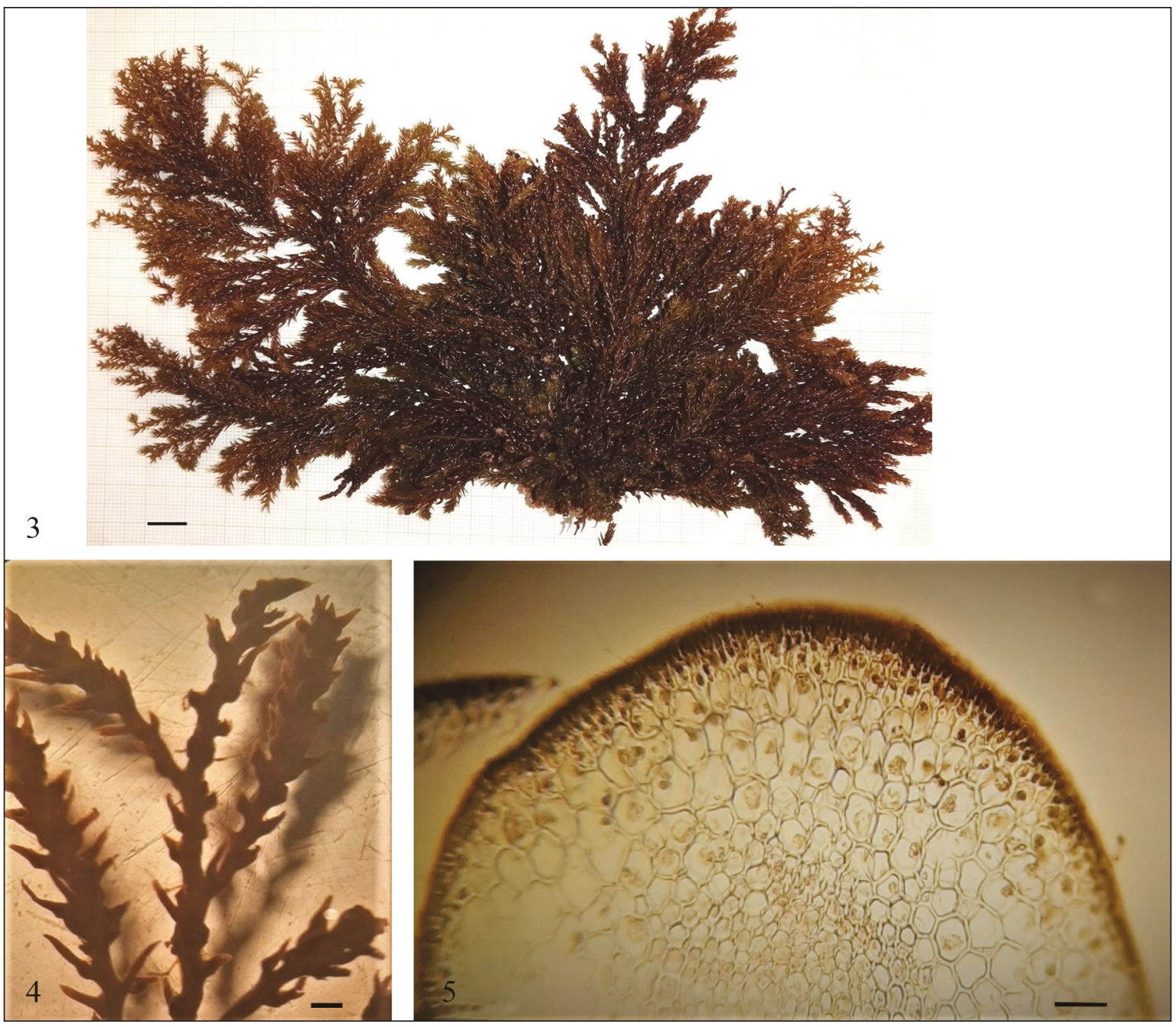

Figures 3-5. Ericaria amentacea (C. Agardh) Molinari et Guiry. Fig. 3: habit of E. amentacea (scale bar: $1 \mathrm{~cm}$ ). Fig. 4: detail of spinose and grouped conceptacles (scale bar: $1 \mathrm{~mm}$ ). Fig. 5: cross section (scale bar: $100 \mu \mathrm{m}$ ).

Garreta et al., 2000). Fertile receptacles have been observed in summer, whereas in autumn this species was not reproductive.

Furnari et al. (2003) reported this species in the bay of Brucoli in 1993 at $1 \mathrm{~m}$ depth.

Ericaria brachycarpa is a caespitose species attached to the substratum by haptera. Gomez Garreta et al. (2000) and Orellana et al. (2019) observed that the apices of this species are smooth and not prominent. On the other hand, for Cormaci et al. (2012) the apical portion of the axis is spinose. During our observations, we noticed that the apical portion is spinose during the vegetative activity, whereas during the senescence period it tends to get smoother.

This species does not present aerocysts neither tophules. Primary and secondary branches are cy- lindrical with spinose appendages. The receptacles at the apices of the terminal branchlets, not compact, are surrounded by spinose appendages, which are very swollen at the base.

This species lives in the upper sublittoral zone, from the surface to several meters' depth (Gómez Garreta et al., 2000).

\section{Cystoseira compressa (Esper) Gerloff et Nizamud- din (Figs. 9-11)}

Cystoseira compressa has been frequently observed throughout the bay of Brucoli. In the bay, usually, this species does not form dense populations but there are some large-sized isolated individuals, especially in the northeastern coast. This 


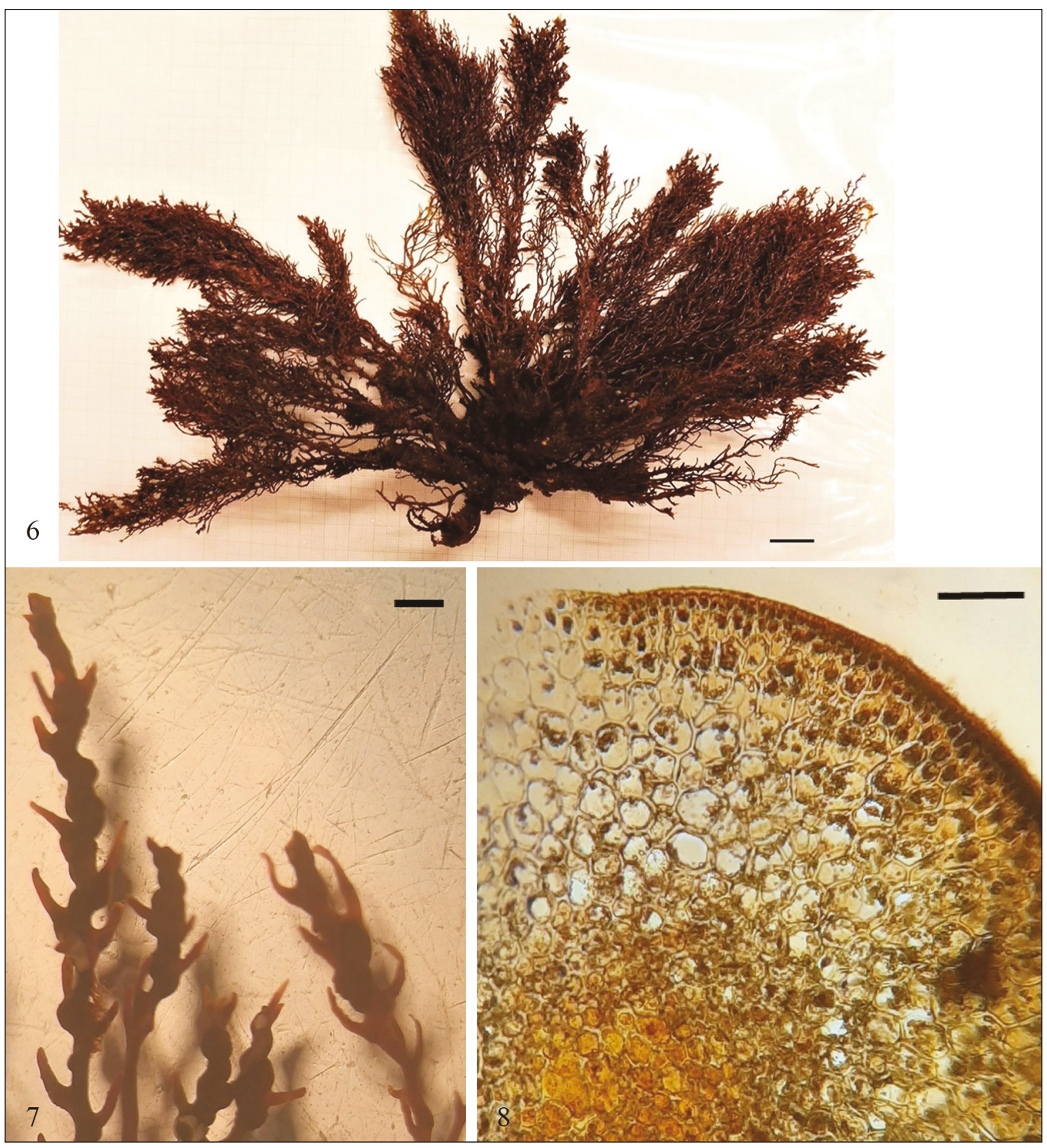

Figures 6-8. Ericaria brachycarpa (J. Agardh) Molinari et Guiry. Fig. 6: habit of E. brachycarpa (scale bar: $1 \mathrm{~cm}$ ). Fig. 7: fertile receptacles (scale bar: $1 \mathrm{~mm}$ ). Fig. 8: cross section (scale bar: $100 \mu \mathrm{m}$ ).

species forms scattered populations with E. mediterranea in the southeast side of the bay, where there are smaller thalli. In the northwest coast, it is even present in the infralittoral fringe with very little individuals without aerocysts. This species was fertile during the summer, but it was not reproductive in autumn. According to the historical data (Battiato \& Ponte, 1975; Battiato et al., 1980; Fur- nari et al., 2003), this species was already present in the bay since 1970 .

The specimens found by us corresponds to the description of Gómez Garreta et al. (2000): it is a caespitose species, which lives in the upper sublittoral zone, in both wave-exposed and sheltered places. The axes, attached to the substratum by a small basal disc, are cylindrical at the apex and flat- 

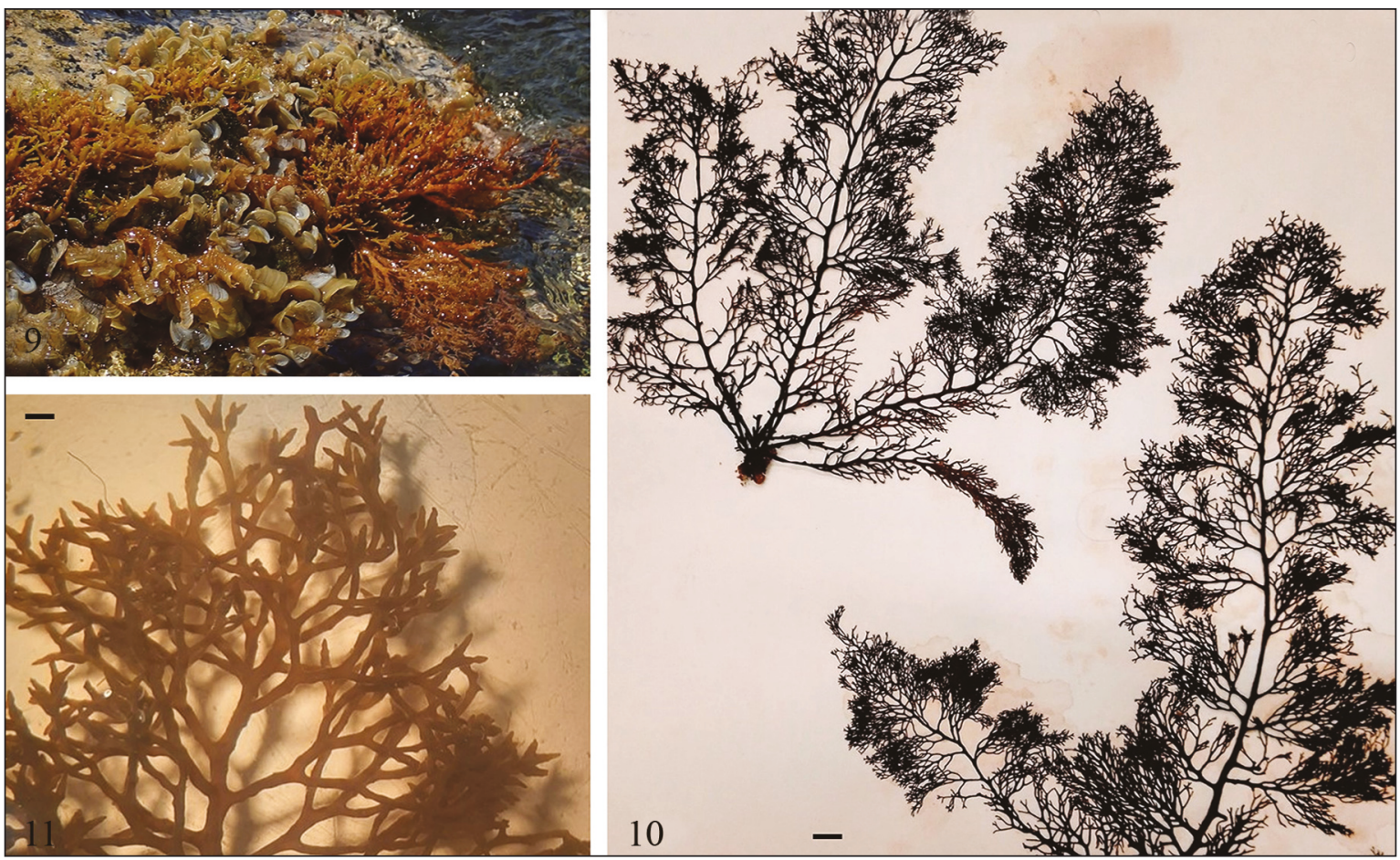

Figures 9-11. Cystoseira compressa (Esper) Gerloff et Nizamuddin. Fig. 9: infralittoral fringe with C. compressa along the northwest coast of the bay of Brucoli (scale bar: $1 \mathrm{~cm}$ ). Fig. 10: thalli stored in exsiccata (scale bar: $1 \mathrm{~cm}$ ). Fig. 11: detail of fertile receptacles (scale bar: $1 \mathrm{~mm}$ ).

tened at the base, especially in spring and summer. In exposed places, such as the northwestern coast of the bay, it is rosette-shaped. Instead, in sheltered places, as in the southeast side of the bay, there are more developed thalli. The apex of the axis is smooth. This species has aerocysts that, especially in summer, are associated with the receptacles formed at the apices of the terminal branchlets.

\section{Gongolaria elegans (Sauvageau) Molinari et Guiry} (Figs. 12-15)

Gongolaria elegans is present in the southeast side and in the northwest side of the bay of Brucoli. In both cases, this species forms scattered populations in association with Gongolaria montagnei var. tenuior (Ercegović) Molinari et Guiry. Fertile receptacles were observed only during the summer.

According to historical data (Furnari et al., 2003), G. elegans was reported in the bay of Brucoli in 1995 at $1 \mathrm{~m}$ depth. This species grows in the upper sublittoral zone to several meters' depth, usually in sheltered situations (Gómez Garreta et al., 2000).
Our specimens of G. elegans correspond to the description of Cormaci et al. (2012): non-caespitose species attached to the substratum by a discoid base, with a short axis, rarely branched, and a spinose and not prominent apex that sometimes makes up a rosette with primary branches sketches. In this species, there are spinose and ovoid tophules with reserve function (Rodríguez-Prieto et al., 2013). Primary branches are cylindrical and without spines at the basal region, while secondary and tertiary branches are cylindrical and surrounded by small spinose appendages. The receptacles, present at the apices of terminal branchelets, carry few conceptacles at the base of spines (Gómez Garreta et al., 2000; Orellana et al., 2019).

Cystoseira foeniculacea (Linnaeus) Greville (Figs. 16-18)

Cystoseira foeniculacea frequently forms scattered population in the northeast side of the bay of Brucoli. According to Gómez Garreta et al. (2000) and Cormaci et al. (2012), the receptacles at the apices of last-order terminal branches, sometimes 


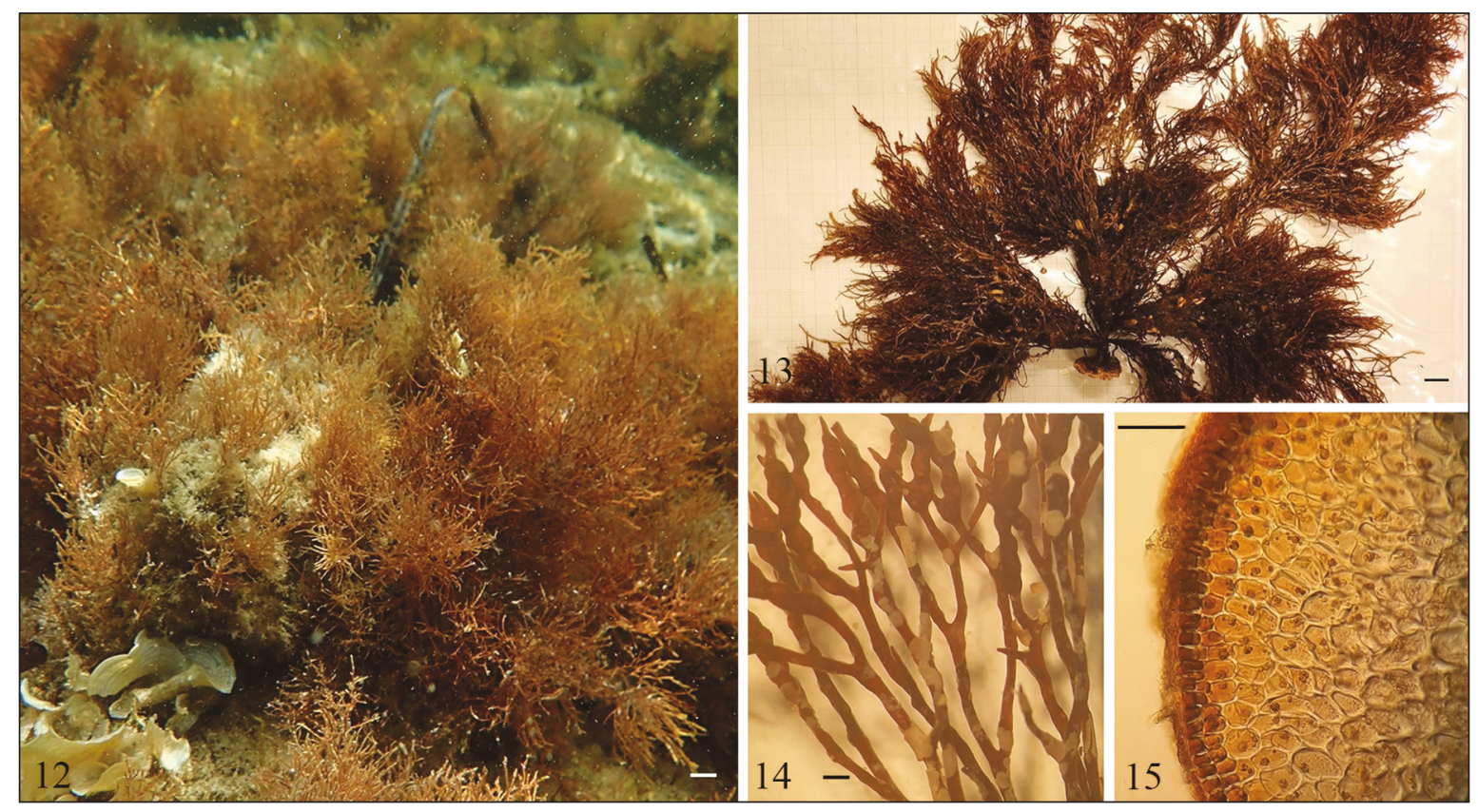

Figures 12-15. Gongolaria elegans (Sauvageau) Molinari et Guiry. Fig. 12: scattered population of G. elegans in the bay of Brucoli (scale bar: $1 \mathrm{~cm}$ ). Fig. 13: Habit of G. elegans (scale bar: $1 \mathrm{~cm}$ ). Fig. 14: fertile receptacles (scale bar: $1 \mathrm{~mm}$ ). Fig. 15: cross-section (scale bar: $100 \mu \mathrm{m}$ ).

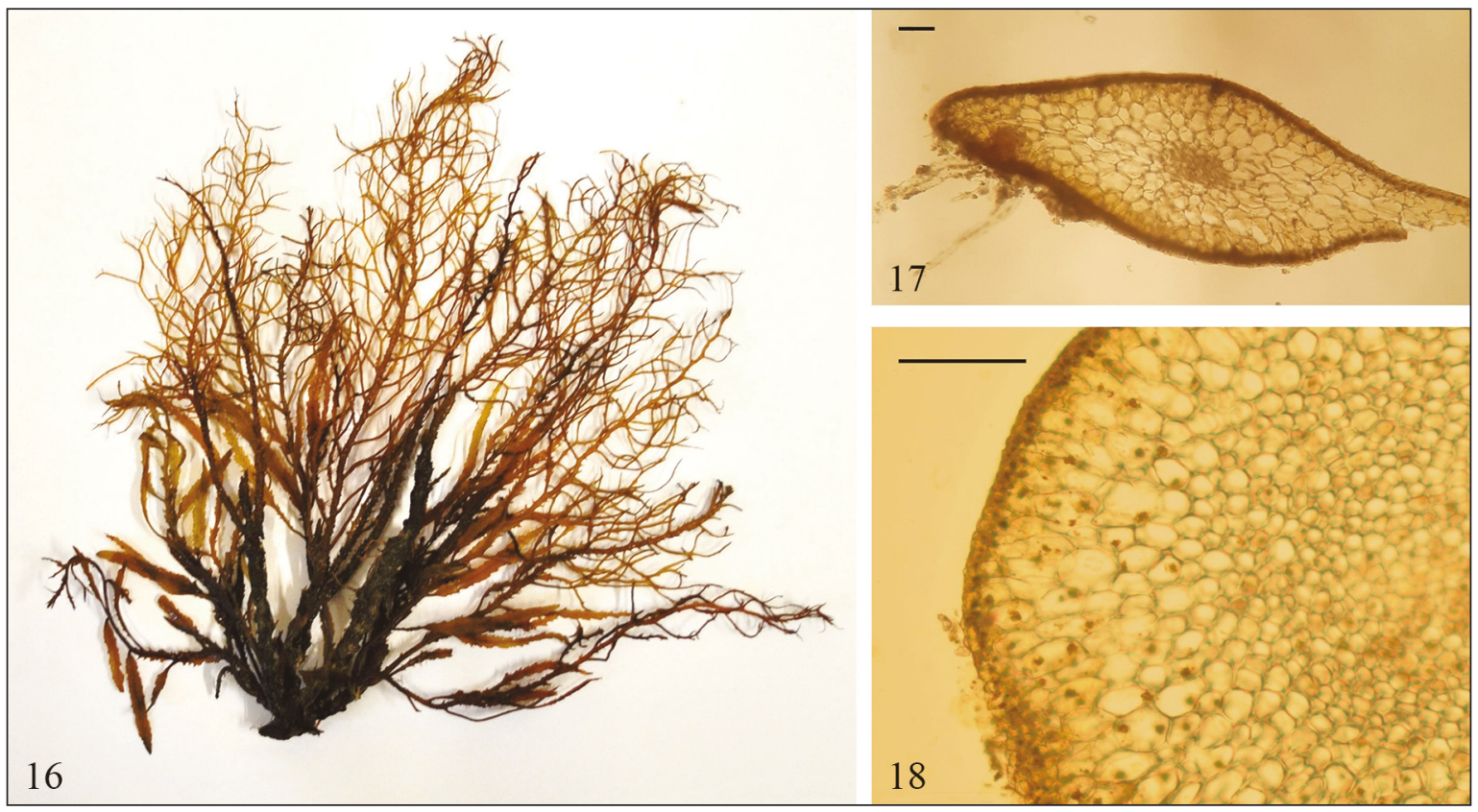

Figures 16-18. Cystoseira foeniculacea (Linnaeus) Greville. Fig. 16: habit of C. foeniculacea (scale bar: $1 \mathrm{~cm}$ ). Fig. 17 : cross-section of flattened primary branches (scale bar: $100 \mu \mathrm{m}$ ). Fig. 18: cross-section of cylindrical primary branches (scale bar: $100 \mu \mathrm{m})$.

on an aerocyst, are compact, lanceolate or fusiform, simple or branched and usually are present in spring and in summer. However, during the entire sampling period, the specimens collected by us were not fertile. Moreover, C. foeniculacea has never been reported in historical data of the bay of Brucoli.

This species grows in sheltered places, in the upper sublittoral zone on the surface or to several 
meters' depth (Gómez Garreta et al., 2000). It is a caespitose species attached to the substratum by a wide and irregular basal disc. The axes are normally spinose with small scars from dehisced primary branches. Apices of the axes are not very prominent, with small spines. Primary branches show a dimorphism: flattened or elliptical in cross-section with distichous secondary ramification or cylindrical in cross-section with alternate ramification in several planes. Secondary branches may be cylindrical or flattened. Foliaceus adventitious branches, with toothed margin and midrib may be present at the base of the plant or the primary branches in autumn and winter. Last order branches are filiform and divaricate. According to Gómez Garreta et al. (2000) and Cormaci et al. (2012), ovoid aerocysts, absent in winter and generally present in the rest of the year, are located at the end of the branches and may be isolated or in series. Nevertheless, during the sampling period, we have never observed the aerocysts.

\section{Cystoseira foeniculacea f. tenuiramosa (Erce-} govic) A. Gómez Garreta, M.C. Barceló, M.A. Ribera et J. Rull Lluch (Figs. 19, 20)

Cystoseira foeniculacea $\mathrm{f}$. tenuiramosa usually forms dense populations in the tidal pools of the eastern side of the bay of Brucoli. Some isolated individuals have been also observed in the northwestern coast in association with populations of $G$. elegans. According to Gómez Garreta et al. (2000), the receptacles, located at the apices of the branches, are surrounded by spinose appendages and are fertile in summer. Nevertheless, during the entire sampling period, we have never observed fertile receptacles of this species. Moreover, C. foeniculacea $\mathrm{f}$. tenuiramosa has never been reported in historical data of the bay of Brucoli.

This species usually occurs in shallow sheltered places as bays, harbours and back of coves (Gómez Garreta et al., 2000). It is caespitose and attached to the substratum by a large irregularly discoid base. Axes are normally spinose with small scars from dehisced primary branches. The apices of the axis are not very prominent and present small spines. Primary branches are cylindrical, covered with spines. Secondary and higher order branches are filiform. In this species, especially in autumn and winter, at the base of the axis or the primary branches, there are foliaceous adventitious branches with toothed margin and midrib.

Cystoseira humilis Schousboe ex Kützing (Figs.

$$
\text { 21, 22) }
$$

Cystoseira humilis is not very frequent in the bay of Brucoli: isolated individuals have been found in the southeast and in the northwest coasts, usually along with population of $C$. compressa. During the summer sampling, this species was fertile, as defined by Gómez Garreta et al. (2000) who stated that receptacles are usually abundant in spring and summer, scarce in autumn and absent in winter.

This species has never been reported in historical data of the bay of Brucoli.
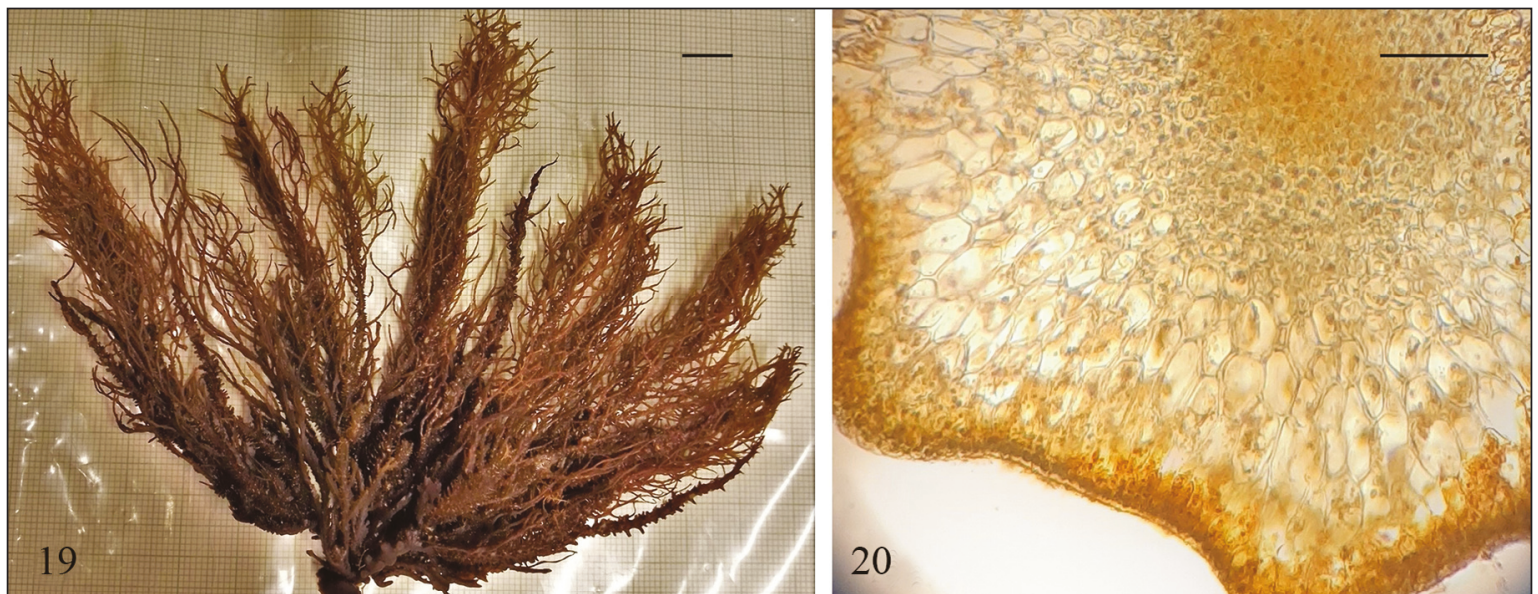

Figures 19-20. Cystoseira foeniculacea f. tenuiramosa (Ercegovic) A. Gómez Garreta, M.C. Barceló, M.A. Ribera et J. Rull Lluch. Fig. 19: habit of $C$. foeniculacea f. tenuiramosa (scale bar: $1 \mathrm{~cm}$ ). Fig. 20: cross-section (scale bar: $100 \mu \mathrm{m}$ ). 


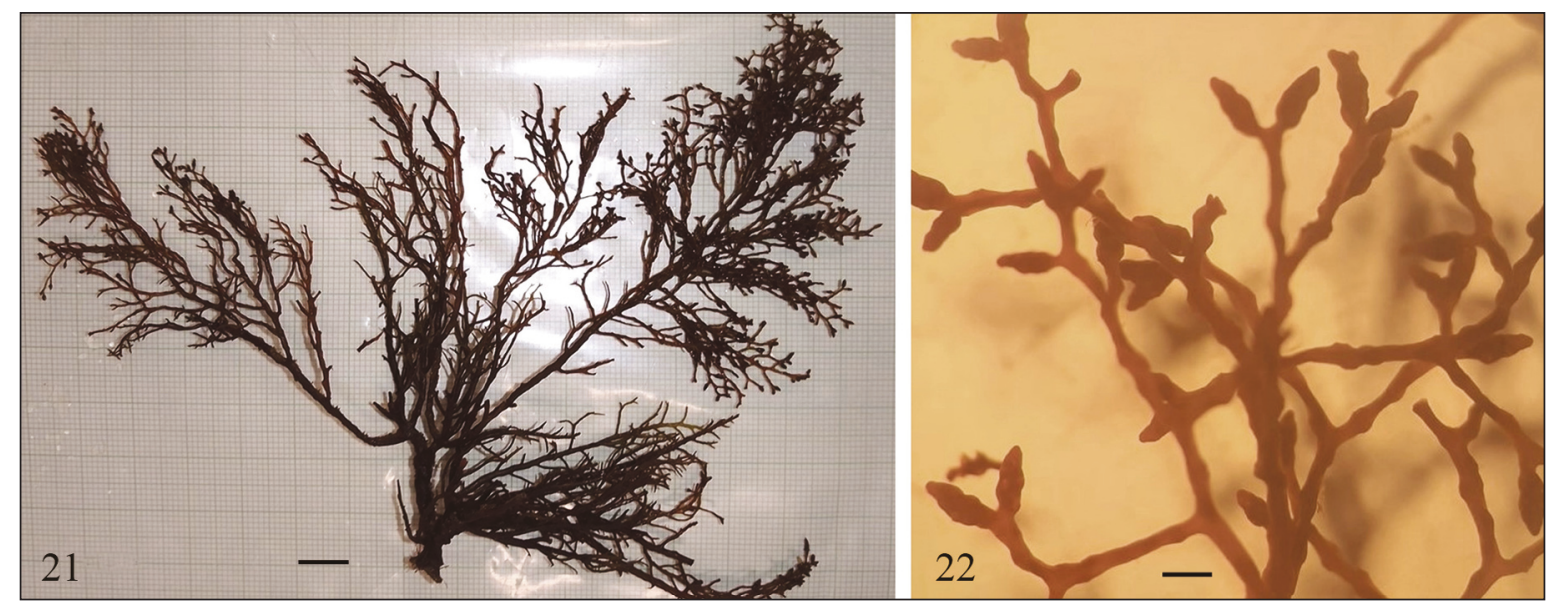

Figures 21-22. Cystoseira humilis Schousboe ex Kützing. Fig. 21: Habit of C. humilis (scal bar: $1 \mathrm{~cm}$ ). Fig. 22: Detail of fertile receptacles (scale bar: $1 \mathrm{~mm}$ ).

Cystoseira humilis usually occurs in tidal pools or in the upper sublittoral zone, in moderately exposed places with warm waters (Gómez Garreta et al., 2000). This species is pseudocaespitose, in fact, the primary axis branches out early. Generally, as observed by Cormaci et al. (2012), the thalli are attached to the substratum by a small basal disc when they are epilithic or by a strong and prominent disc when they are epiphytic on other species. The axes are short, cylindrical and thin with smooth and not very prominent apices. Primary branches are generally cylindrical but, especially in epiphytic thalli, they could be slightly flattened at the bases (Gómez Garreta et al., 2000; Cormaci et al., 2012). Secondary and tertiary branches are filiform, simple or branched. Moreover, according to Gómez Garreta et al. (2000), Cormaci et al. (2012) and even in our specimens, the aerocysts are small and the receptacles at the apices of the terminal branchlets are cylindrical, fusiform, simple or irregularly branched.

Ericaria mediterranea (Sauvageau) Molinari et Guiry (Figs. 23-26)

In the east side of the bay of Brucoli, E. mediterranea is usually situated just below the E. amentacea belts. In the southeast coast, dense populations have been observed with few thalli of C. compressa. During the summer sampling, we observed fertile receptacles of this species, as confirmed by Gómez Garreta et al. (2000) who stated that this species is usually reproductive in spring and summer.
Ericaria mediterranea has never been documented in historical data on the Fucales of Brucoli.

This species usually occurs in wave-exposed or moderately exposed places, in the upper sublittoral zone always near the surface (Gómez Garreta et al., 2000; Rodríguez-Prieto et al., 2013).

Our specimens of E. mediterranea correspond to the descriptions of Gómez Garreta et al. (2000) Cormaci et al. (2012) and Rodríguez-Prieto et al. (2013): non-caespitose habit with a short axis attached to the substratum by independent or partially fused haptera, apex of the axis not prominent and covered with spines, primary branches cylindrical with a pyramidal shape, all branches covered with spinose appendages, receptacles compact and surrounded by short spinose appendages.

\section{Gongolaria montagnei var. tenuior (Ercegović) Molinari et Guiry (Figs. 27-29)}

Gongolaria montagnei var. tenuior is very common in the bay of Brucoli: dense populations are present on both the east and northwest coasts, frequently associated with population of T. elegans. During the summer sampling, this species was fertile with evident receptacles with small spines swollen at the base, whereas it was not reproductive in autumn.

This species has been reported in historical data of the bay of Brucoli by Battiato et al. (1980) as Cystoseira adriatica in the upper sublittoral zone of the bay, and by Furnari et al. (2003) as Cystoseira spinosa var. tenuior at $5 \mathrm{~m}$ depth. 


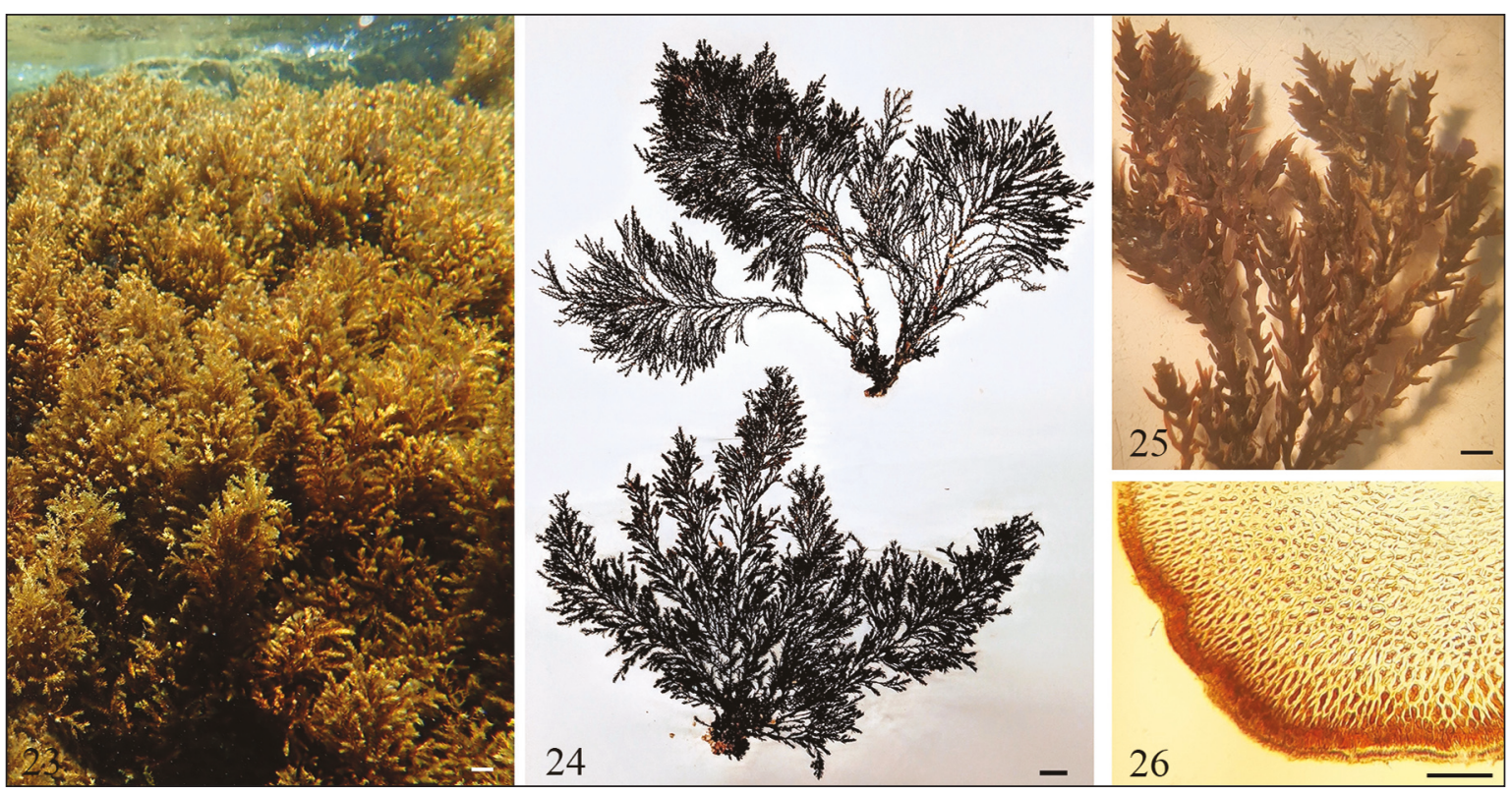

Figures 23-26. Ericaria mediterranea (Sauvageau) Molinari et Guiry. Fig. 23: dense populations of E. mediterranea in the bay of Brucoli (scale bar: $1 \mathrm{~cm}$ ). Fig. 24: thalli stored in exsiccata (scale bar: $1 \mathrm{~cm})$. Fig. 25: detail of fertile receptacles (scale bar: $1 \mathrm{~mm}$ ). Fig. 26: cross-section (scale bar: $100 \mu \mathrm{m}$ ).

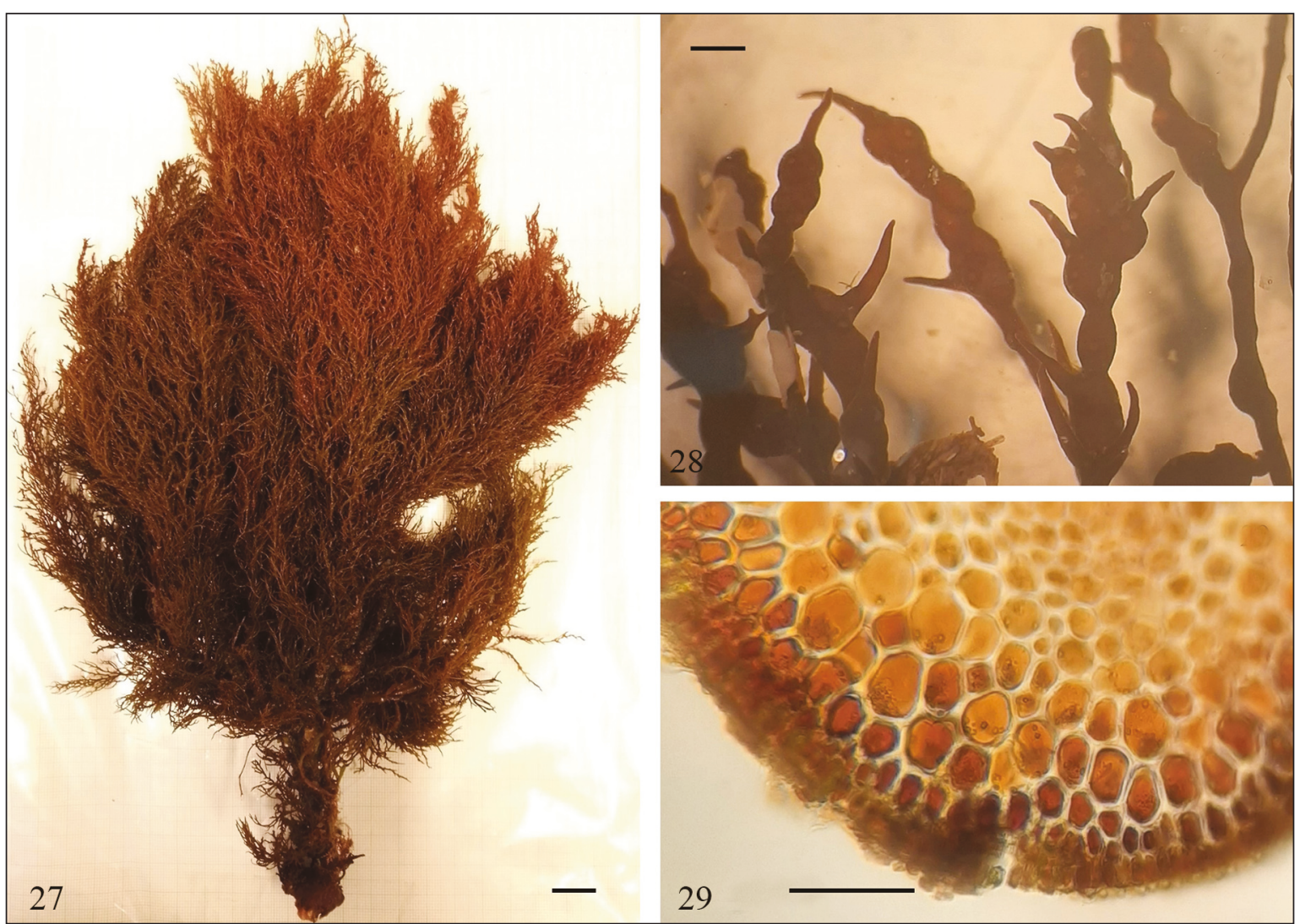

Figures 27-29. Gongolaria montagnei var. tenuior (Ercegović) Molinari et Guiry. Fig. 27: habit of G. montagnei var tenuior (scale bar: $1 \mathrm{~cm}$ ). Fig. 28: fertile receptacles (scale bar: $1 \mathrm{~mm}$ ). Fig. 29: Cross-section (scale bar: $100 \mu \mathrm{m}$ ). 
G. montagnei var. tenuior is a non-caespitose species attached to the substratum by a basal disc. It frequently grows in the upper sublittoral zone, in both exposed and sheltered coasts. Apex of the axis is not prominent and with spines. Primary branches are initially cylindrical and then flattened with spinose appendages. Secondary branches are shorter and less branched, always with spines. This species has approximated tophules spinose and oblong, sometimes rough and smooth for ageing. They are distributed particularly near the apex, as stated by Rodríguez-Prieto et al. (2013). Conceptacles at the base of the spinose appendages are initially scattered but become grouped in receptacles at the apices of the terminal branchlets. As observed by Gómez Garreta et al. (2000), Cormaci et al. (2012) and, even in our specimens, this species is usually fertile in spring and summer.

Sargassum vulgare C. Agardh, nom. illeg. (Figs. 30-32)

Sargassum vulgare has been frequently observed throughout the bay of Brucoli: isolated individuals, usually associated with populations of $C y$. compressa, are present in both the east and the northwest coasts. We observed fertile thalli of this species during the summer sampling, as confirmed by Gómez Garreta et al. (2000) and Cormaci et al. (2012) who stated that this species is usually reproductive in summer and spring.
S. vulgare has been reported in the bay of Brucoli in 1970 (Furnari et al., 2003). This species usually grows in the upper sublittoral zone, on moderately exposed rocks or in rocks pools (Gómez Garreta et al., 2000).

The specimens collected by us correspond to the descriptions of Gómez Garreta et al. (2000), Cormaci et al. (2012) and Rodríguez-Prieto et al. (2013). This species has a short main axis, attached to the substratum by basal disc. Primary branches are cylindrical smooth or thorny in young parts, scarcely branched. Secondary branches are similar to the primary. Foliaceous branches are lanceolate with serrate or slightly wavy margins and with a very prominent midrib. Aerocysts are spherical and located on a short pedicel. Fertile branches, formed at the axilla of foliaceous branches, consist of a short sterile pedicel carrying numerous receptacles warty, fusiform, simple or bifurcate.

\section{DISCUSSION}

Many of the species historically present in the bay of Brucoli have been not found anymore (Table 1).

In particular, Gongolaria sauvageauana (Hamel) Molinari \& Guiry, G. barbata (Stackhouse) Kuntze, and Ericaria crinita (Duby) Molinari \& Guiry have not been seen again in the bay. However, four
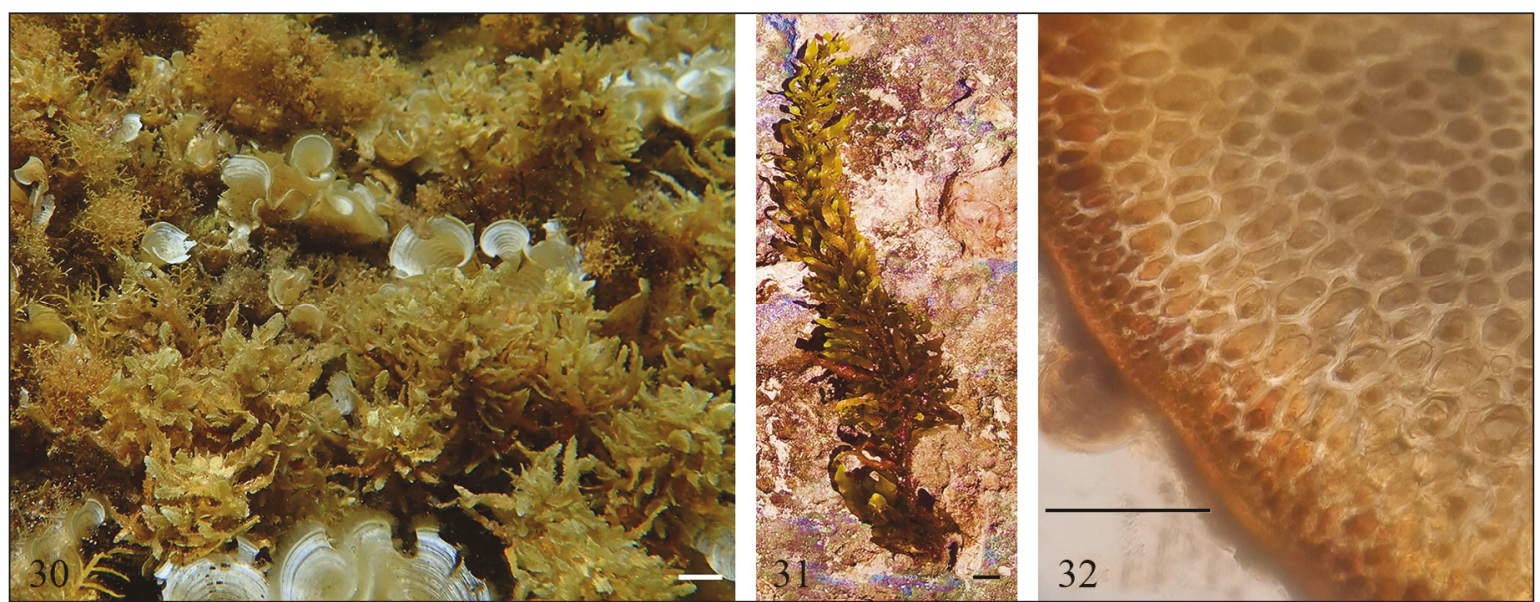

Figures 30-32. Sargassum vulgare C. Agardh. Fig. 30: isolated individuals of $S$. vulgare with populations of C. compressa found in the bay of Brucoli (scale bar: $1 \mathrm{~cm}$ ). Fig. 31: habit of a specimen (scale bar: $1 \mathrm{~cm}$ ). Fig. 32: cross-section (scale bar: $100 \mu \mathrm{m})$ 


\begin{tabular}{|c|c|c|}
\hline Taxon & Historical data & $\begin{array}{c}\text { Current } \\
\text { distribution }\end{array}$ \\
\hline $\begin{array}{l}\text { Ericaria amentacea } \\
\text { (C. Agardh) Molinari et Guiry }\end{array}$ & $\begin{array}{l}\text { as Cystoseira stricta, infralittoral fringe (A) } \\
\text { as Cystoseira amentacea v. stricta, 1974, } \\
\text { infralittoral fringe (B) }\end{array}$ & Present \\
\hline $\begin{array}{l}\text { Ericaria brachycarpa } \\
\text { (J. Agardh) Molinari et Guiry }\end{array}$ & $\begin{array}{l}\text { as Cystoseira brachycarpa, 1993, at } 1 \mathrm{~m} \text { depth } \\
\text { (B) }\end{array}$ & Present \\
\hline $\begin{array}{l}\text { Cystoseira compressa } \\
\text { (Esper) Gerloff et Nizamuddin }\end{array}$ & $\begin{array}{l}\text { as Cystoseira fimbriata, at } 30 \mathrm{~m} \text { depth (C) } \\
\text { as Cystoseira compressa, in the upper } \\
\text { infralittoral zone (A) } \\
\text { as C. compressa, } 1970 \text {, at } 0,5 \mathrm{~m} \text { depth (B) }\end{array}$ & Present \\
\hline $\begin{array}{l}\text { Gongolaria elegans } \\
\text { (Sauvageau) Molinari et Guiry }\end{array}$ & as Cystoseira elegans, 1995, at $1 \mathrm{~m}$ depth (B) & Present \\
\hline $\begin{array}{l}\text { Cystoseira foeniculacea } \\
\text { (Linnaeus) Greville }\end{array}$ & Not reported in historical data & Present \\
\hline $\begin{array}{l}\text { Cystoseira foeniculacea f. } \\
\text { tenuiramosa (Ercegovic) } \\
\text { A. Gómez Garreta, } \\
\text { M.C. Barceló, M.A.Ribera et } \\
\text { J. Rull Lluch }\end{array}$ & Not reported in historical data & Present \\
\hline $\begin{array}{l}\text { Cystoseira humilis } \\
\text { Schousboe ex Kützing }\end{array}$ & Not reported in historical data & Present \\
\hline $\begin{array}{l}\text { Ericaria mediterranea } \\
\text { (Sauvageau) Molinari et Guiry }\end{array}$ & Not reported in historical data & Present \\
\hline $\begin{array}{l}\text { Gongolaria montagnei var. } \\
\text { tenuior (Ercegović) Molinari } \\
\text { et Guiry }\end{array}$ & $\begin{array}{l}\text { as Cystsoeira adriatica, in the upper } \\
\text { infralittoral zone (A) } \\
\text { as Cystoseira spinosa var. tenuior, at } 5 \mathrm{~m} \\
\text { depth (B) }\end{array}$ & Present \\
\hline $\begin{array}{l}\text { Gongolaria sauvageauana } \\
\text { (Hamel) Molinari et Guiry }\end{array}$ & $\begin{array}{l}\text { as Cystoseira sauvageauana, } 1970 \text {, at } 0,5 \mathrm{~m} \\
\text { depth (B) }\end{array}$ & Not present \\
\hline $\begin{array}{l}\text { Gongolaria barbata } \\
\text { (Stackhouse) Kuntze }\end{array}$ & $\begin{array}{l}\text { as Cystoseira barbata,1992-1993, at 0,5 m } \\
\text { depth (B) }\end{array}$ & Not present \\
\hline $\begin{array}{l}\text { Gongolaria montagnei } \\
\text { (J. Agardh) Kuntze }\end{array}$ & $\begin{array}{l}\text { as Cystoseira adriatica, at } 30 \mathrm{~m} \text { depth (D) } \\
\text { as Cystoseira spinosa, 1993, at } 15 \mathrm{~m} \text { depth (B) }\end{array}$ & Not present \\
\hline $\begin{array}{l}\text { Ericaria crinita (Duby) } \\
\text { Molinari et Guiry }\end{array}$ & $\begin{array}{l}\text { as Cystoseira crinita, in the upper infralittoral } \\
\text { zone (A) }\end{array}$ & Not present \\
\hline $\begin{array}{l}\text { Sargassum vulgare } \\
\text { C. Agardh }\end{array}$ & $1970(\mathrm{~B})$ & Present \\
\hline
\end{tabular}

Table 1. Presence of the Fucales in the bay of Brucoli in historical data $[\mathrm{A}=$ (Battiato et al., 1980); $\mathrm{B}=($ Furnari et al., 2003) $\mathrm{C}=($ Battiato and Ponte, 1975); $\mathrm{D}=($ Battiato et al.,1978) $]$ and current status. 
species ( $C$. foeniculacea, $C$. foeniculacea f. tenuiramosa, $C$. humilis and $E$. mediterranea), never reported in the bay of Brucoli, have been found during the sampling period. Six of the species historically present in the bay, are still there today: $E$. amentacea, E. brachycarpa, C. compressa, G. elegans, G. montagnei var. tenuior, S. vulgare. Therefore, the total number of species remained almost stable.

Nevertheless, the disappearance of some species and the presence of others in the bay of Brucoli could represent a change in environmental conditions. Consequently, the presence of $E$. mediterranea in the bay could be related to the increase of fresh waters, due to upwelling phenomena, in particular to groundwater infiltrations caused by anthropic activities (Relini \& Tunesi, 2009). This might be indicative of an increase in the flow rate of the estuary of Channel Porcaria, which could have contributed to a change in the hydrodynamic regime of the area. Regarding $C$. foeniculacea, $C$. foeniculacea f. tenuiramosa and $C$. humilis, we believe that, since these species are typical of tidal pools and shallow waters, maybe they were already present in the bay, but probably in the previous works of the bay of Brucoli, these habitats have been less studied.

During the sampling period, all species were fertile, except to $C$. foeniculacea and C. foeniculacea f. tenuiramosa, which have never been seen reproductive. Moreover, it is noteworthy that throughout the bay of Brucoli the most representative species is $C$. compressa. Indeed, large-sized thalli have frequently been observed in the whole bay. This species is indicative of anthropized environments with moderately polluted waters (Relini \& Giaccone, 2009). In fact, it can tolerate pollution, growing even in harbors. Therefore, the presence of this species in the bay could denote the occurrence of mesotrophic waters, probably due to the sewage. From this point of view, the presence of the sewage may have contributed to disappearance of some species, particularly of those most sensitive to pollution. Many of the Fucales are absent in the southwest coast and in the central sector where there are floating piers. The area richest in species is the northeast coast, while entering the bay the number of species of Fucales decreases, being replaced by less structured species, such as Halopteris scoparia (Linnaeus) Sauvageau, Padina pavonica (Linnaeus) Thivy and geniculate coral- line algae. Therefore, it would be important to improve the quality of water, especially in the sector nearby the sewage, with a wastewater treatment system. Once the main causes of regression have been removed, it could be conceivable to suggest a restoration program with the reintroduction of the species historically present in this area. Finally, it would be desirable to establish a marine protected area (MPA) to encourage the conservation of the Posidonia oceanica meadow and the Fucales assemblages of the bay of Brucoli.

\section{ACKNOWLEDGEMENTS}

I am grateful to Dr. Lombardo A. and Dr. Villardita P. for their technical support in the collection, sorting and storage of samples. Moreover, I want to thank Prof. Alongi G. and Dr. Catra M. for their assistance in the identification of species.

\section{REFERENCES}

Agnetta D., Badalamenti F., Ceccherelli G., Di Trapani F., Bonaviri C. \& Gianguzza P., 2015. Role of two co-occurring Mediterranean sea urchins in the formation of barren from Cystoseira canopy. Estuarine, Coastal and Shelf Science, 152: 73-77.

Airoldi L., Ballesteros E., Buonuomo R., Van Belzen J., Bouma T.J., Cebrian E., De Clerk O., Engelen A.H., Ferrario F., Fraschetti S., Gianni F., Guidetti P., Ivesa L., Mancuso F.P., Micheli F., Perkol-Finkel S., Serrao E.A., Strain E.M. \& Mangialajo L., 2014. Marine forests at risk: solutions to halt the loss and promote the recovery of Mediterranean canopy-forming seaweeds. p. 28-33. In: Proceedings of the $5^{\text {th }}$ Mediterranean Symposium on Marine Vegetation. Portoroz, 27-28 October 2014. Slovenia.

Airoldi L. \& Beck M.W., 2007. Loss, status and trends for coastal marine habitats of Europe. Oceanography and Marine Biology: An Annual Review, 45: 345-405.

Asnaghi V., Chiantore M., Bertolotto R.-M., Parravicini V., Cattaneo-Vietti R., Gaino F., Moretto P., Privitera D. \& Mangialajo L., 2009. Implementation of the European Water Framework Directive: Natural variability associated with the CARLIT method on the rocky shores of the Ligurian Sea (Italy). Marine Ecology, 30: 505-513.

https://doi.org/10.1111/j.1439-0485.2009.00346.x

Ballesteros E., 1988. Estructura y dinámica de la comunidad de Cystoseira mediterranea Sauvageau en el Mediterráneo Noroccidental. Investigacion Pesquera, 52: 313-334.

Ballesteros E., 1990a. Structure and dynamics of the community of Cystoseira zosteroides (Turner) C. 
Agardh (Fucales, Phaeophyceae) in the Northwestern Mediterranean. Scientia Marina: 54: 217-299.

Ballesteros E., 1990b. Structure and dynamics of the Cystoseira caespitosa Sauvageau (Fucales, Phaeophyceae) community in the North-Western Mediterranean. Scientia Marina, 54: 155-168.

Ballesteros E., Torras X., Pinedo S., Garcia M., Mangialajo L. \& de Torres M., 2007. A new methodology based on littoral community cartography for the implementation of the European Water Framework Directive. Marine Pollution Bulletin, 55: 172-180.

Battiato A., Cormaci M. \& Furnari G., 1980. Alghe marine della costa Iblea. Atti III Convegno Siciliano di Ecologia: La Natura e l'Uomo. Noto, Ispica. Cooperativa Universitaria Libraria Catanese (CULC) Press, Catania, 38 pp.

Battiato A., Duro A. \& Galluzzo G., 1978. Flora sommersa della baia di Brucoli (Siracusa); secondo contributo, con osservazioni preliminari sui briozoi. Bollettino dell'Accademia Gioenia, 13: 105.

Battiato A. \& Ponte A., 1975. Flora sommersa della Baia di Brucoli (Siracusa). Primo contributo. Atti Accademia Gioenia Scienze Naturali, Catania, 7 : 93-99.

Benedetti-Cecchi L., Pannacciulli F., Bulleri F., Moschella P.S., Airoldi L., Relini G., \& Cinelli F., 2001. Predicting the consequences of anthropogenic disturbance: large- scale effects of loss of canopy algae on rocky shores. Marine Ecology Progress Series, 214: $137-150$

Commission, E., 2000. Water Framework Directive (2000/60/EC), Official Journal of the European Communities.

Connell S., Foster M. \& Airoldi L., 2014. What are algal turfs? Towards a better description of turfs. Marine Ecology Progress Series, 495: 299-307.

Cormaci M., Furnari G., Alongi G., Catra M., Pizzuto F. $\&$ Serio D., 2001. Spring marine vegetation on rocky substrata of the Tremiti Islands (Adriatic Sea, Italy). In Mediterranean Ecosystems (pp. 245-254). Springer, Milano.

Cormaci M., Furnari G., Catra M., Alongi G. \& Giaccone G., 2012. Flora marina bentonica del Mediterraneo: Phaeophyceae. Bollettino dell'Accademia Gioenia, 45 (375): 1-508.

Council of Europe, 1979. Convention de Berne - Convention relative à la conservation de la vie sauvage et du milieu naturel de l'Europe. Série des traités européens, 104. Conseil de l'Europe, Strasbourg.

Dayton P.K., 1985. Ecology of kelp communities. Annual Review of Ecology, Evolution and Systematics, 16: 215-245.

Feldmann J., 1937. Recherches sur la végétation marine de la Méditerranée. La côte des Albères. Revue Algologique, 10: 73-254.

Furnari G, Giaccone G, Cormaci M, Alongi G \& Serio D., 2003. Biodiversità marina delle coste italiane: Catalogo del macrofitobenthos. Biologia Marina Mediterranea, 10: 3-483.
Giaccone G., 1973. Écologie et chorologie des Cystoseira de Méditerranée. Rapports de la Communauté Internationale de la Mer Méditerranée, 22: 49-50.

Giaccone G., Alongi G., Pizzuto F. \& Cossu A., 1994. La Vegetazione marina bentonica fotofila del Mediterraneo: 2: Infralitorale e Circalitorale: proposte di aggiornamento. Bollettino dell'Accademia Gioenia, 27 (346): 111-157.

Gómez Garreta A., Barceló M.C., Gallardo T., Pérez-Ruzafa I., Ribera M.A. \& Rull J., 2001. Flora Phycologica Iberica. Vol. 1. Fucales. Universidad de Murcia, Servicio de Publicaciones, 192 pp.

Halpern B.S., Walbridge S., Selkoe K.A., Kappel C.V., Micheli F., D’Agrosa C., Bruno J.F., Casey K.S., Ebert C., Fox H.E., Fujita R., Heinemann D., Lenihan H.S., Madin E.M.P., Perry M.T., Selig E.R., Spalding M., Steneck R. \& Watson R., 2008. A global map of human impact on marine ecosystems. Science, 319 (5865): 948-952.

Harley C.D.G., Randall Hughes A., Hultgren K.M., Miner B.G., Sorte C.J.B., Thornber C.S., Rodriguez L.F., Tomanek L. \& Williams S.L., 2006. The impacts of climate change in coastal marine systems. Ecology Letters, 9: 228-241.

Mancuso F.P., Strain E.M.A., Piccioni E., De Clerck O., Sarà G. \& Airoldi L., 2018. Status of vulnerable Cystoseira populations along the Italian infralittoral fringe, and relationships with environmental and anthropogenic variables. Marine Pollution Bulletin, 129: 762-771.

Mangialajo L., Chiantore M. \& Cattaneo-Vietti R., 2008. Loss of fucoid algae along a gradient of urbanisation, and structure of benthic assemblages. Marine Ecology Progress Series, 358: 63-74.

Mangialajo L., Ruggieri N., Asnaghi V., Chiantore M., Povero P. \& Cattaneo-Vietti R., 2007. Ecological status in the Ligurian Sea: the effect of coastline urbanisation and the importance of proper reference sites. Marine Pollution Bulletin, 55: 30-41.

Messina V., 2013 A contribution to the knowledge of epiphytic flora on the leaves of the seagrass Cymodocea nodosa Ucria (Ascherson) (Najadales, Potamogetonaceae) of the "Bay of Brucoli" (south-eastern Sicily). Bollettino dell'Accademia Gioenia, 46 (376): 41-48.

Micheli F., Levin N., Giakoumi S., Katsanevakis S., Abdulla A., Coll M., Fraschetti S., Kark S., Koutsoubas D., Mackelworth P., Maiorano L. \& Possingham H.P., 2013. Setting priorities for regional conservation planning in the Mediterranean Sea. PloS One, 8 (4): e59038

Mineur F., Arenas F., Assis J., Davies A.J., Engelen A.H., Fernandes F., Malta E., Thibaut T., Van Nguyen T., Vaz-Pinto F., Vranken S., Serrão E.A. \& De Clerck O., 2015. European seaweeds under pressure: Consequences for communities and ecosystem functioning. Journal of Sea Research, 98: 91108.

Molinier R., 1960. Etude des biocénoses marines du Cap Corse. Vegetatio, 9: 217-312. 
Nisi A., 2012. Analysis of the Posidonia oceanica (L.) Delile (Najadales, Potamogetonaceae) of the "Bay of Brucoli” (sud-eastern Sicily). Bollettino dell'Accademia Gioenia, 45 (375): 607 - 629.

Ollivier G., 1929. Etude de la flore marine de la Côte d'Azur. Annales de l'Institut Océanographique de Paris, 7: 53-173.

Orellana S., Hernández M. \& Sansón M., 2019. Diversity of Cystoseira sensu lato (Fucales, Phaeophyceae) in the eastern Atlantic and Mediterranean based on morphological and DNA evidence, including Carpodesmia gen. emend. and Treptacantha gen. emend.. European Journal of Phycology, 54: 447465.

Perkol-Finkel S. \& Airoldi L., 2010. Loss and recovery potential of marine habitats: an experimental study of factors maintaining resilience in subtidal algal forests at the Adriatic Sea. PLoS One, 5: e10791.

Pignatti S., 1962. Associazioni di alghe marine sulla costa veneziana. Memorie del Reale Istituto Veneto di Scienze, Lettere ed Arti, Venezia, Italia, 134 pp.

Relini G. \& Tunesi L., 2009. Le specie protette del protocollo SPA/BIO (Convenzione di Barcellona) presenti in Italia. Schede descrittive per l'identificazione. Biologia Marina Mediterranea, 16: 1-433.

Relini G. \& Giaccone G., 2009. Gli habitat prioritari del protocollo SPA/BIO (Convenzione di Barcellona) presenti in Italia. Schede descrittive per l'identificazione. Biologia Marina Mediterranea, 16: $1-367$.

Rodríguez-Prieto C., Ballesteros E., Boisset F. \& AfonsoCarrilo J., 2013. Guía de las macroalgas y fanerógamas marinas del Mediterráneo Occidental. Ediciones Omega, Barcelona, 656 pp.

Sales M. \& Ballesteros E., 2009. Shallow Cystoseira (Fucales: Ochrophyta) assemblages thriving in sheltered areas from Menorca (NW Mediterranean): relationships with environmental factors and anthropogenic pressures. Estuarine, Coastal and Shelf Science, 84: 476-482.

Sales M., Cebrian E., Tomas F. \& Ballesteros E., 2011. Pollution impacts and recovery potential in three species of the genus Cystoseira (Fucales, Heterokontophyta). Estuarine, Coastal and Shelf Science, 92 : 347-357.

Sauvageau C., 1912. A propos des Cystoseira de Banyuls et de Guéthary. Bulletin de la Station Biologique d'Arcachon, $14: 1$ - 424.

Schiel D.R. \& Foster M.S., 2006. The population biology of large brown seaweeds: ecological consequences of multiphase life histories in dynamic coastal environments. Annual Review of Ecology, Evolution, and Systematics, 37: 343-372.

Serio D., Alongi G., Catra M., Cormaci M. \& Furnari G., 2006. Changes in the benthic algal flora of Linosa Island (Straits of Sicily, Mediterranean Sea). Botanica Marina, 49: 135-144.

Soltan D., Verlaque M., Boudouresque C.F. \& Francour P., 2001. Changes in macroalgal communities in the vicinity of a Mediterranean sewage outfall after the setting up of a treatment plant. Marine Pollution Bulletin, $42: 59-70$.

Steneck R.S., Graham M.H., Bourque B.J., Corbett D., Erlandson J.M., Estes J.A. \& Tegner M.J., 2002. Kelp forest ecosystems: biodiversity, stability, resilience and future. Environmental Conservation, 29: 436-459.

Strain E.M.A., Thomson R.J., Micheli F., Mancuso F.P. \& Airoldi L., 2014. Identifying the interacting roles of stressors in driving the global loss of canopy-forming to mat-forming algae in marine ecosystems. Global Change Biology, 20: 3300-3312.

Templado J., 2014. Future trends of Mediterranean biodiversity. p. 479-498. In: The Mediterranean Sea: its History and Present Challenges. Goffredo S., Dubinsky Z. (Eds.), Springer, Netherlands.

Thibaut T., Blanfuné A., Boudouresque C.F., Cottalorda J.M., Hereu B., Susini M.-L. \& Verlaque M., 2016 Unexpected temporal stability of Cystoseira and Sargassum forests in Port-Cros, one of the oldest Mediterranean marine national parks. Cryptogamie Algologie, 37: 1-30.

Thibaut T., Blanfuné A., Boudouresque C.F. \& Verlaque M., 2015. Decline and local extinction of Fucales in French Riviera: the harbinger of future extinctions? Mediterranean Marine Science, 16: 206-224.

Thibaut T., Blanfuné A., Markovic L., Verlaque M., Boudouresque C.F., Perret-Boudouresque M., Maćic V. \& Bottin L., 2014. Unexpected abundance and longterm relative stability of the brown alga Cystoseira amentacea, hitherto regarded as a threatened species, in the north-western Mediterranean Sea. Marine Pollution Bulletin, 89: $305-323$.

Thibaut T., Pinedo S., Torras X. \& Ballesteros E., 2005. Long-term decline of the populations of Fucales (Cystoseira spp. and Sargassum spp.) in the Albères coast (France, north-western Mediterranean). Marine Pollution Bulletin, 50: 1472-1489.

Tsiamis K., Panayotidis P., Salomidi M., Pavlidou A., Kleinteich J., Balanika K. \& Küpper F.C., 2013. Macroalgal community response to re-oligotrophication in Saronikos Gulf. Marine Ecology Progress Series, 472: $73-85$.

UNEP/MAP, 2009. Report of the 16th Ordinary Meeting of the Contracting Parties to the Convention for the Protection of the Marine Environment and the Coastal Region of the Mediterranean and its Protocols, Marrakesh, Morocco, 3-5 November 2009. UNEP, Mediterranean Action Plan, Athens, $321 \mathrm{pp}$

Vergés A., Alcoverro T. \& Ballesteros E., 2009. Role of fish herbivory in structuring the vertical distribution of canopy algae Cystoseira spp. in the Mediterranean Sea. Marine Ecology Progress Series, 375 : 1-11.

Waycott M., Duarte C., Carruthers T. J., Orth R.J., Dennison W.C., Olyarnik S., Calladine A., Fourqurean J.W., Heck K.L., Hughes A.R., Kendrick G.A., Kenworthy W.J., Short F.T. \& Williams S.L., 2009. Accelerating loss of seagrasses across the globe 
threatens coastal ecosystems. Proceedings of the National Academy of Sciences, 106 (30): 12377 12381.
Worm B. \& Lotze H.K., 2006. Effects of eutrophication, grazing, and algal blooms on rocky shores. Limnology and Oceanography, 51: 569-579. 
